\title{
The Minister's Housing Allowance: Should It Stand, and If Not, Can Its Challengers Show Standing?
}

\author{
Bryce Langford*
}

\section{INTRODUCTION}

On November 13, 2014, ministers across the United States were able to breathe a collective sigh of relief. ${ }^{1}$ On that day the Seventh Circuit vacated a lower court judgment that held that tax exclusions granted exclusively to "ministers of the gospel" violated the Establishment Clause and were therefore unconstitutional. ${ }^{2}$ The Seventh Circuit declined to rule on whether the tax exclusions for ministers violated the Establishment Clause; instead, Circuit Judge Joel Martin Flaum, writing for a three-judge panel, held only that the plaintiffs in the case lacked standing to challenge the tax provisions. ${ }^{3}$

Section 107 of the Internal Revenue Code contains two provisions that allow "ministers of the gospel" to deduct from their income the rental or mortgage value of a home as well as the cost of utilities and maintenance for the home. ${ }^{4}$ Section 107(1) (hereinafter the Parsonage Allowance) allows ministers to deduct from their income the value of a house provided to the minister by the church or religious organization. ${ }^{5}$ Section 107(2) (hereinafter the Minister's Housing Allowance) allows ministers who are not provided a home by their church or religious

\footnotetext{
* J.D. Candidate 2016, University of Kansas School of Law; B.A. History 2013, West Texas A\&M University. Thank you to Grant Brazill and Professor Michael Davis for your edits and direction in writing this paper. I would also like to mention that before attending law school, I was previously a minister who claimed the tax exemption that is the subject of this Comment. Ultimately, I want to thank my wife, Sara. Thank you for your patience and kindness towards mewhile I have been a minister, a law student, and all times in between.

1. Sarah Eekhoff Zylstra, Good News for Pastors: Court Overturns Atheist Victory on Housing Allowance, CHRISTIANITY TODAY (Nov. 13, 2014, 4:40 PM), http://www.christ ianitytoday.com/gleanings/2014/november/good-news-pastors-court-overturns-atheist-housingallowance.html.

2. Freedom from Religion Found., Inc. v. Lew, 773 F.3d 815, 818 (7th Cir. 2014).

3. Id.

4. 26 U.S.C. $\S 107$ (2012).

5. Id. $\S 107(1)$.
} 
organization to deduct from their income the value of a home purchased or rented by the minister. ${ }^{6}$ The plain text of the tax code explicitly states that this exemption applies only to "ministers of the gospel."

Just one year before the Seventh Circuit's opinion, Judge Barbara Crabb for the Western District of Wisconsin held in Freedom from Religion Foundation, Inc. v. Lew (Lew) that tax exclusions granted exclusively to "ministers of the gospel" violated the Establishment Clause. ${ }^{8}$ In Lew, Judge Crabb ultimately determined that since the exemption explicitly applied to only religious persons and not other similarly situated individuals, the exemption was unconstitutional. ${ }^{9}$ The Seventh Circuit, however, vacated the district court judgment and held that the plaintiffs lacked standing because they never actually applied for the tax exemption, were never denied the tax exemption, and therefore suffered no actual injury from the tax exemption. ${ }^{10}$ As of April 2015, the plaintiffs in Lew were considering whether to appeal their case to the Supreme Court. ${ }^{11}$

The district court's decision in Lew was covered by many news sources, including the Huffington Post. ${ }^{12}$ The Wisconsin State Journal called the judgment a "stunning court victory" for the Freedom from Religion Foundation (FFRF). ${ }^{13}$ Commenting on the article published by the Wisconsin State Journal, the Christian Legal Society stated, "[i]f this section (of the tax code) were invalidated, the consequences for retired ministers could run the gamut from reduced standard of living to true want." 14 Clergy TaxNet, a clergy tax advice blog, stated that the ruling would have "an enormous impact on clergy around the country.",

6. Id. $\S 107(2)$

7. Id. $\S 107$.

8. Freedom from Religion Found., Inc. v. Lew, 983 F. Supp. 2d 1051, 1053 (W.D. Wis. 2013), vacated, 773 F.3d 815 (7th Cir. 2014).

9. Id.

10. Freedom from Religion Found., Inc. v. Lew, 773 F.3d 815, 821 (7th Cir. 2014).

11. Telephone Interview with Rebekah Markert, Legal Counsel, Freedom from Religion Foundation (Feb. 6, 2015).

12. See Sarah Pulliam Bailey, Clergy Tax-Free Housing Allowance Ruled Unconstitutional; Freedom From Religion Foundation Wins Federal Suit, The Huffington Post (Nov. 25, 2013, 6:57 PM), http://www.huffingtonpost.com/2013/11/25/clergy-tax-free-housing-unconstitutional_n_ 4339673.html.

13. Doug Erickson, In the Spirit: Clergy Members Blast Back at Court Ruling that Could Cost them Millions, THE Wisconsin STATE JouRnal (July 28, 2014, 9:30 AM), http://host. madison.com/lifestyles/faith-and-values/religion/in-the-spirit-clergy-members-blast-back-at-courtruling/article_dd3881c5-0945-5ee7-bfec-032d260b2104.html.

14. Id.

15. Clergy TAXNet, https://clergytaxnet.com/blog/?paged=3 (last visited May 24, 2015) (accessed by going to November 2013 in Monthly Archives list). 
One report, published in 2002, estimated that ministers would save $\$ 2.3$ billion in taxes through the exemption between the years 2002 and 2007. ${ }^{16}$ Some reports estimate the tax exclusion is worth $\$ 700$ million a year. ${ }^{17}$ According to another report, about $87 \%$ of ministers claim the Minister's Housing Allowance. ${ }^{18}$

This Comment has three primary components. Part II of this Comment will examine the history of the Minister's Housing Allowance. Part III will examine the issue of standing and the difficulties of establishing standing to challenge tax provisions. Part IV will show how, regardless of standing, the Minister's Housing Allowance violates the Establishment Clause because: (1) it does not have a secular purpose; (2) it can be reasonably seen as a government endorsement of religion; (3) it fosters excessive entanglement between government and religion; (4) it is not rooted in an historical tradition; and (5) it violates government neutrality with religion.

\section{BACKGROUND}

Before discussing the standing and Establishment Clause issues, it is important to understand the substance of the Minister's Housing Allowance as well as its history. This requires a brief look at the Internal Revenue Code and some tax provisions. It also requires a discussion of religious tax exemptions going back to colonial America.

\section{A. Understanding the Minister's Housing Allowance}

The Parsonage Exemption and Minister's Housing Allowance are codified in 26 U.S.C. $\S 107$ :

In the case of a minister of the gospel, gross income does not include (1) the rental value of a home furnished to him as part of his compensation; or (2) the rental allowance paid to him as part of his compensation, to the extent used by him to rent or provide a home and to the extent such allowance does not exceed the fair rental value of the

16. Freedom from Religion Found., Inc. v. Lew, 983 F. Supp. 2d, 1051, 1054 (W.D. Wis. 2013), vacated, 773 F.3d 815 (7th Cir. 2014).

17. Sarah Eekhoff Zylstra, Are Pastors' Homes that Different?, Christianity TODAy (June 24, 2014), http://www.christianitytoday.com/ct/2014/june/are-pastors-homes-that-different.html.

18. $I d$. 
home, including furnishings and appurtenances such as a garage, plus the cost of utilities.

It is important to distinguish between the two sections. Section 107(1) allows ministers to exclude from their income a house provided by their church or religious employer. This is similar to Internal Revenue Code $\S 119$, which provides similar tax exclusions for secular employees who are provided residence as part of their compensation. ${ }^{20}$ A major rationale for the Parsonage Exemption is that the provision of the house by the employer or the church is for the convenience of the employer-this is also known as the "Convenience of the Employer Doctrine." $" 11$

The Convenience of the Employer Doctrine describes a tax exclusion for employees who are required to live on the business premises as a condition of their employment. ${ }^{22}$ Therefore, the provision of the house is not for the benefit of the employee, but rather the benefit is for the convenience of the employer. ${ }^{23}$ An example would be a hotel manager who is required to live at the hotel in order to properly carry out his duties as a manager. ${ }^{24}$ It is not the hotel manager who is receiving the benefit; rather, it is the hotel owners who are receiving the benefit of having the manager available on the premises at all times. The rationale is the same under the Parsonage Exemption. In providing a home to a minister, the church is getting the benefit that the minister is available to members of the congregation outside of corporate gatherings. Therefore, the employer benefits by providing access to the minister for the entire congregation.

Section 107(2) is different from section 107(1) in that the Minister's Housing Allowance is an exemption for the rentals or payments made on a house that is not provided for by the religious organization. ${ }^{25}$ Put simply, the Parsonage Exemption excludes the home itself from gross income, while the Minister's Housing Allowance excludes the income spent on the rental or payments for a home. ${ }^{26}$ The tax exclusion also extends to the cost of utilities spent on the home (such as gas, electric,

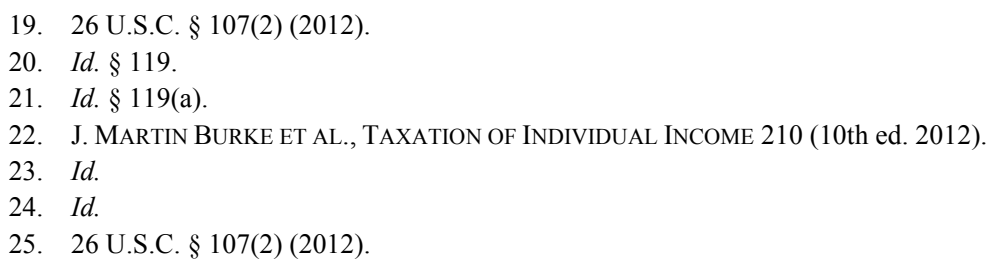


and water bills) as well as to repairs made to the home, so long as the repairs do not exceed the fair market value of the home. $^{27}$

In summary, the Parsonage Exemption allows a minister to exclude from his gross income the value of the house given to him by his religious employer. ${ }^{28}$ The Minister's Housing Allowance allows a minister to exclude from gross income the rent and payments made for a house not provided by his employer. ${ }^{29}$ Under the Minister's Housing Allowance, the minister may also exclude from gross income the cost of utilities and repairs or improvements to the home. ${ }^{30}$

\section{B. The History of the Minister's Housing Allowance}

Religious tax exemptions for persons and entities have a long history in America. ${ }^{31}$ In their book Politics, Taxes, and the Pulpit, Nina Crimm and Laurence Winer write that tax exemptions for priests and other classes of people based on religion were a part of some colonial charters as far back as the mid-seventeenth century. ${ }^{32}$ Although some religious tax exemptions under state laws may be traced back to colonial times, the Parsonage Exemption was not codified in federal law until the Revenue Act of $1921 .^{33}$ The original exemption only applied to housing that was provided by a church; therefore, ministers who were not provided housing could not exclude from their income the value of their housing. ${ }^{34}$

In 1954, Congress revised the statute and added $\S 107(2)$, which created the Minister's Housing Allowance. ${ }^{35}$ The date of this amendment is significant. In 1954, the United States was in between the Korean War and the early years of the Vietnam War and was concerned with the spread of communism. ${ }^{36}$ In the same year the Minister's Housing Allowance was codified, the words "under God" were also

\footnotetext{
27. Treas. Reg. $\S 1.107-1(c)(2014)$.

28. 26 U.S.C. $\$ 107(1)$.

29. Id. § $107(2)$.

30. Treas. Reg. § 1.107-1(c).

31. Nina J. Crimm \& Laurence H. Winer, Politics, TaXes and the Pulpit: Provocative FiRST AMENDMENT CONFLICTS 30 (2011).

33. Matthew W. Foster, Note, The Parsonage Allowance Exclusion: Past, Present, and Future, 44 VAND. L. REV. 149, 151 (1991).

34. Id.

35. Freedom from Religion Found., Inc. v. Lew, 983 F. Supp. 2d 1051, 1067 (W.D. Wis. 2013), vacated, 773 F.3d 815 (7th Cir. 2014).

36. Emily D. Newhouse, Comment, I Pledge Allegiance to the Flag of the United States of America: One Nation Under No God, 35 TEX. TECH L. REV. 383, 387 (2004).
} 
added to pledge of allegiance. ${ }^{37}$ The purpose of amending the pledge of allegiance "was to "acknowledge the dependence of [the American] people and ... Government upon the moral directions of the Creator' while simultaneously 'deny[ing] the atheistic and materialistic concepts of communism." "38 Considering the context of the threat of communism, it is important to note the comments of Representative Peter Mack, a congressman from Illinois. ${ }^{39}$

Representative Mack was the sponsor for the 1954 law, which codified the Minister's Housing Allowance. ${ }^{40}$ Speaking before the House Committee on Ways \& Means in 1953, Representative Mack stated the following in support of the Minister's Housing Allowance:

Certainly, in these times when we are being threatened by a godless and anti-religious world movement we should correct this discrimination against certain ministers of the gospel who are carrying on such a courageous fight against this. Certainly this is not too much to do for these people who are caring for our spiritual welfare. ${ }^{41}$

Representative Mack's statements that "we should correct this discrimination against certain ministers" can be explained by another comment from a House committee report from 1954:

Under present law, the rental value of a home furnished a minister of the gospel as a part of his salary is not included in his gross income. This is unfair to those ministers who are not furnished a parsonage, but who receive larger salaries (which are taxable) to compensate them for expenses they incur in supplying their own home. Your committee has removed the discrimination in existing law by providing that the present exclusion is to apply to rental allowances paid to ministers to the extent used by them to rent or provide a home.

The legislative history gives two reasons for the creation of the Minister's Housing Allowance. The first reason proposed to cure a

\footnotetext{
37. Id. 2340).

38. Id. (quoting H.R. REP. NO. 83-1693, at 1-2 (1954), reprinted in 1954 U.S.C.C.A.N. 2339,

39. Wes Smith, Peter F. Mack Jr., Congressman in the '50s, CHI. TRIB. (July 7, 1986), http://articles.chicagotribune.com/1986-07-07/news/8602180025_1_mr-mack-naval-reserve-federalaviation-act.

40. Freedom from Religion Found., Inc. v. Lew, 983 F. Supp. 2d 1051, 1068 (W.D. Wis. 2013), vacated, 773 F.3d 815 (7th Cir. 2014) (quoting General Revenue Revision: Hearings Before the H. Comm. On Ways and Means, 83rd Cong. 1574-75 (1953) (statement of Peter F. Mack, Jr.)).

41. Id. (emphasis added).

42. Id. at 1067 (quoting H.R. REP. NO. 83-1337, at 15 (1954), reprinted in 1954 U.S.C.C.A.N. 4035, 4040).
} 
defect that minister's then receiving the Minister's Housing Allowance were no longer discriminated against simply because their church did not provide them with a parsonage. ${ }^{43}$ The second reason proposed that ministers who were "carrying on the fight" against "a godless and antireligious world movement" were rewarded for their efforts in caring for America's "spiritual welfare." 44

Following passage in 1954, the Minister's Housing Allowance remained largely unchanged until 2002. In 2002 the House of Representatives passed the Clergy Housing Allowance Clarification Act of 2002. ${ }^{45}$ The Act was passed in response to a case involving a pastor in California before the Ninth Circuit. ${ }^{46}$ In Warren v. Commissioner of Internal Revenue, ${ }^{47}$ a minister had claimed approximately $\$ 80,000$ in taxexempt housing allowance income. ${ }^{48}$ To prevent abuses of the Minister's Housing Allowance, $\S 107(2)$ was amended to include the words "fair market value." ${ }^{\prime 9}$ The Internal Revenue Service also ruled that a rental allowance may only be used for one home and could not be used to support a second home. ${ }^{50}$

\section{Freedom from Religion Foundation v. Lew}

The FFRF is a non-profit organization whose purpose is to "promote the constitutional principle of separation of state and church, and to educate the public on matters relating to nontheism." ${ }^{\text {, }}$ Two copresidents of the FFRF, Annie Laurie Gaylor and Dan Barker, individually along with the FFRF, ${ }^{52}$ brought a lawsuit in the Western District of Wisconsin alleging that both the Parsonage Exemption and the

43. Id.

44. Id. at 1068 (quoting General Revenue Revision: Hearings Before the H. Comm. On Ways and Means, 83rd Cong. 1574-75 (1953)).

45. Erwin Chemerinsky, The Parsonage Exemption Violates the Establishment Clause and Should be Declared Unconstitutional, 24 WhITTIER L. REV. 707, 708 (2003).

46. Id.; see also Warren v. Comm'r, 282 F.3d 1119 (9th Cir. 2002).

47. Warren, 282 F.3d at 1119.

48. See Chemerinsky, supra note 45 , at 708 . It is important to note that the $\$ 80,000$ claimed by this minister was not the entire value of his home. Rather, this was the money he spent on the rent or mortgage, along with utilities in one taxable year. The tax code only allows exclusions for the taxable year of income spent on the home. See 26 U.S.C. $\$ 107$ (2012).

49. Id. § 107(2) (2012).

50. Treas. Reg. § 1.107-1(c) (2014).

51. FREEDOM From RELIGION FoundATION, http://ffr.org/faq/item/14999-what-is-the-found ations-purpose (last visited May 24, 2015).

52. Freedom from Religion Found., Inc. v. Lew, 983 F. Supp. 2d, 1051, 1052 (W.D. Wis. 2013), vacated, 773 F.3d 815 (7th Cir. 2014). 
Minister's Housing Allowance violated the Establishment Clause. ${ }^{53}$ Specifically, the FFRF claimed unequal treatment because only "ministers of the gospel" were able to claim the tax exclusion even though portions of Barker and Gaylor's salaries from the FFRF were designated as a housing allowance. ${ }^{54}$

The suit was brought against the Secretary of the Department of the Treasury and the Commissioner of the Internal Revenue Service. ${ }^{55}$ Originally, the FFRF challenged both the Parsonage Exemption and the Minister's Housing Allowance. ${ }^{56}$ Defendants filed for summary judgment, and the FFRF did not oppose defendants' motion for summary judgment as to the Parsonage Exemption issue. ${ }^{57}$ The district court granted defendant's motion for the Parsonage Exemption, but the court entered summary judgment sua sponte for the FFRF on their claim against the Minister's Housing Allowance. ${ }^{58}$

In its opinion, the court first addressed defendants' argument that the FFRF lacked standing to challenge the Minister's Housing Allowance. ${ }^{59}$ The court concluded that FFRF had standing because they were injured by having been denied an exemption that others receive, their injury was fairly traceable to the conduct of the defendants in their capacity for implementing the tax code, and their injury was redressable by enjoining further enforcement of $\S 107(2) .^{60}$

The court next moved to the merits of plaintiffs' claim. ${ }^{61}$ The court ultimately ruled that the Minister's Housing Allowance violated the Establishment Clause because it did not have a secular purpose and had the effect of government endorsement of religion. ${ }^{62}$ The court, relying on the Supreme Court's ruling in Texas Monthly, Inc. v. Bullock, ${ }^{63}$ ultimately held that the exception violated the Establishment Clause "because the exemption provides a benefit to religious persons and no one else, even though doing so is not necessary to alleviate a special burden on religious exercise." ${ }^{24}$ In Texas Monthly, a plurality of the

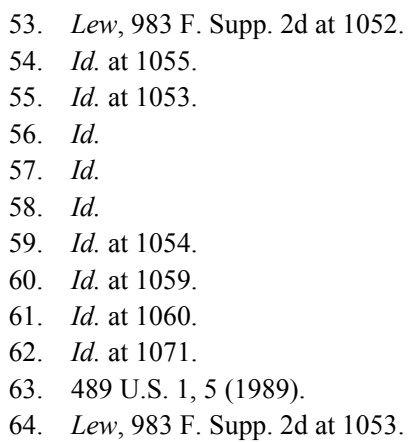


Supreme Court ruled that tax exemptions granted exclusively to religious publications violated the Establishment Clause because they were available only to religious publications and not other, non-religious publications. $^{65}$

Upon review of Judge Crabb's decision in the district court, the Seventh Circuit disagreed with the conclusion on the issue of standing. ${ }^{66}$ The court noted that the standing issue is particularly rigorous and "elusive" in Establishment Clause cases. ${ }^{67}$ Circuit Judge Flaum highlighted three ways that a plaintiff can demonstrate standing in an Establishment Clause case. ${ }^{68}$ The first is that "plaintiffs may demonstrate standing based on the direct harm of what is claimed to be an establishment of religion, such as a mandatory prayer in a public school classroom." 69 The second way to establish standing is under the Flast test, ${ }^{70}$ in which a taxpayer may establish standing when a "congressional action under the taxing and spending clause is in derogation of [the Establishment Clause]." "71 The third way a plaintiff can establish standing in an Establishment Clause case is when an individual has "incurred a cost or been denied a benefit on account of their religion... such as when the availability of a tax exemption is conditioned on religious affiliation."72 It was this third method relied upon by the FFRF in Lew. $^{73}$

The Seventh Circuit rejected this argument, stating, "[w]ithout a request, there can be no denial." 74 Since the individual plaintiffs Gaylor and Barker never personally asked for the exemption and were subsequently denied, the Seventh Circuit reasoned that they were not actually injured. ${ }^{75}$ "A plaintiff cannot establish standing to challenge such a [tax] provision without having personally claimed and been denied the exemption.",76

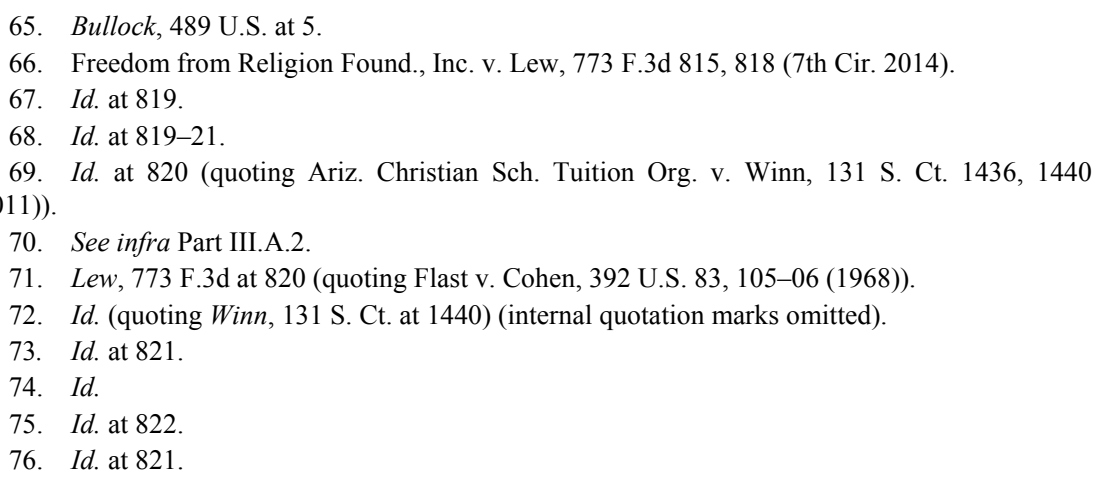


The Seventh Circuit further rejected the FFRF's argument that plaintiffs had standing because they were "similarly situated" individuals to "ministers of the gospel."77 The court said that the plaintiffs still failed to show a legally cognizable injury, they had not actually claimed the exemption, and the term "similarly situated" was too vague to demonstrate standing. ${ }^{78}$

Judge Crabb, in her district court opinion, wrote that requiring the plaintiffs to actually apply for the exemption and be denied would "serve no legitimate purpose" because the plaintiffs were not "ministers of the gospel" and the "alleged injury is clear from the face of the statute.",79 The Seventh Circuit rejected this argument. ${ }^{80}$ Circuit Judge Flaum wrote, "[i]n any case, "[t]he assumption that if [the plaintiffs] have no standing to sue, no one would have standing is not a reason to find standing." " J1 Judge Flaum explained that "Article III 'is not merely a troublesome hurdle to be overcome if possible so as to reach the 'merits' of a lawsuit which a party desires to have adjudicated; it is a part of the basic charter promulgated by the Framers." " 82

Circuit Judge Flaum concluded by saying, "[a] person suffers no judicially cognizable injury merely because others receive a tax benefit that is conditioned on allegedly unconstitutional criteria, even if that person is otherwise 'similarly situated' to those who do receive the benefit." 83 Therefore, it did not matter whether the Minister's Housing Allowance violates the Constitution - it only mattered that the plaintiffs had not applied for and been denied the exemption. ${ }^{84}$ As stated above, Circuit Judge Flaum declined to discuss in any detail the merits of the FFRF's claim. ${ }^{85}$

As of early 2015, the plaintiffs in Lew were deciding whether or not they would petition the Supreme Court for certiorari. ${ }^{86}$ The plaintiffs

\footnotetext{
77. Id. at 823 .

78. Id.

79. Freedom from Religion Found., Inc. v. Lew, 983 F. Supp. 2d 1051, 1055-56 (W.D. Wis. 2013), vacated, 773 F.3d 815 (7th Cir. 2014).

80. Freedom from Religion Found. Inc. v. Lew, 773 F.3d 815, 824-25 (7th Cir. 2014).

81. Id. at 824 (quoting Schlesinger v. Reservists Comm. to Stop the War, 418 U.S. 208, 227 (1974)).

82. Id. at 825 (quoting Valley Forge Christian Coll. v. Americans United for Separation of Church and State, Inc., 454 U.S. 464, 476 (1982)).

83. Id.

84. Id.

85. Id. at 818 .

86. Telephone Interview with Rebekah Markert, Legal Counsel, Freedom from Religion Foundation (Feb. 6, 2015).
} 
were considering two options. ${ }^{87}$ The first option was to claim the exemption and see if they were denied. ${ }^{88}$ The second option was to petition for certiorari; however, if the plaintiffs petitioned for certiorari, they would only be arguing their standing issue before the Supreme Court and not the merits of their claim regarding the Minister's Housing Allowance. ${ }^{89}$

\section{The Significance of the Minister's Housing Allowance}

In nearly every town in every state throughout the country, there are ministers who are claiming the Minister's Housing Allowance. ${ }^{90}$ For small towns and rural communities, the ministers may have very meager salaries and the Allowance allows them to keep working in ministry. Often, the minister's house is viewed as an extension of the church building itself, and many of these ministers provide counseling and public interest work free of charge to the community at their homes. ${ }^{91}$ Eliminating the Allowance would mean that ministers' taxable gross income would increase and ministers would have to pay higher taxes. Presumably, some ministers may have to leave their congregations if the churches or institutions are not able to supplement the minister's salary.

On the other hand, every taxpayer in the United States is bearing the tax burden created by the Minister's Housing Allowance. Even though it may be a small burden when distributed across the millions of taxpayers, it is a burden nonetheless on every taxpayer. Eliminating the Allowance would increase the government's tax revenue, and these resources could be allocated for the general welfare. Some estimates indicate that $\$ 700$ million annually would be added to the tax revenue by eliminating the Allowance. $^{92}$

In sum, the Minister's Housing Allowance matters. It matters to every minister, it matters to every taxpayer, and it matters to the general public. Fortunately, however, there are other options available to Congress if the Minister's Housing Allowance is indeed in conflict with

\footnotetext{
87. Id.

88. Id.

89. Id.

90. See Sarah Eekhoff Zylstra, Are Pastors' Homes that Different?, CHRISTIANITY TODAY (June 24, 2014), http://www.christianitytoday.com/ct/2014/june/are-pastors-homes-that-differe nt.html (explaining that approximately $87 \%$ of ministers claim the Minister's Housing Allowance while only $11 \%$ claim the Parsonage Exemption).

91. Id.

92. $I d$.
} 
the Establishment Clause. If Congress created a corresponding tax provision that applied to non-religious non-profits, the Allowance could then benefit more people in more ways. Other non-profits could be more competitive in attracting top-tier managers and employees because of the tax exclusion. These non-profits could also save some money that would have otherwise been spent supplementing salaries, and instead spend such money on programs and resources that directly benefit the general public.

\section{ANALYSIS}

\section{A. The Issue of Standing}

This Comment, just as in the Lew case, will examine standing before examining whether the Minister's Housing Allowance violates the Establishment Clause. While the purpose of this Comment is to show that the Minister's Housing Allowance cannot pass any Establishment Clause test the Supreme Court has developed, a discussion and understanding of the issue of standing is essential to understanding Lew. Even though the Minister's Housing Allowance appears to violate the Establishment Clause on its face, the Allowance has never been successfully challenged. The Allowance has never been successfully challenged because no plaintiff has been able to overcome the significant hurdle of standing.

In Lujan v. Defenders of Wildlife, ${ }^{93}$ Justice Scalia set forth a threepronged test to determine whether a plaintiff has standing. The plaintiff must show: (1) they have suffered an injury in fact; (2) the injury must be fairly traceable to the conduct or action of the defendant; and (3) the injury will likely be redressed by a favorable Court decision. ${ }^{94}$ Judge Crabb ultimately ruled in Lew that the FFRF had standing to challenge the Minister's Housing Allowance. ${ }^{95}$ However, the Seventh Circuit reversed on the issue of standing. ${ }^{96}$

93. 504 U.S. 555 (1992).

94. Id. at $560-61$.

95. Freedom from Religion Found., Inc. v. Lew, 983 F. Supp. 2d 1051, 1059 (W.D. Wis. 2013), vacated, 773 F.3d 815 (7th Cir. 2014).

96. Freedom from Religion Found., Inc. v. Lew, 773 F.3d 815, 818 (7th Cir. 2014). 
1. The History of Taxpayer Standing and the Establishment Clause

"Standing is the determination of whether a specific person is the proper party to bring a matter to the court...."97 The issue becomes more complicated when the person bringing the claim is a taxpayer seeking a remedy for a tax provision that the taxpayer claims has injured him. ${ }^{98}$

In 1923, the Supreme Court ruled in Massachusetts v. Mellon ${ }^{99}$ that a taxpayer could not establish standing simply by claiming an "interest in the moneys of the treasury" because the moneys of the treasury are "shared with millions of others, [and the taxpayer's interest] is comparatively minute and indeterminable."100 In essence, the Court was saying that a taxpayer cannot get standing simply by being a taxpayer because the "injury" that the taxpayer receives is so minute and spread out over the millions of taxpayers who are also "injured."

This more difficult and complicated standing test was successfully met once, in the 1968 Supreme Court case Flast v. Cohen. ${ }^{102}$ In Flast, the Court recognized a taxpayer's standing in an Establishment Clause case where federal funds were being distributed to religious schools. ${ }^{103}$ The Court stated there was "no absolute bar in Article III to suits by federal taxpayers challenging allegedly unconstitutional federal taxing and spending programs." 104 However, subsequent Supreme Court cases have limited the scope of Flast to cases where the government was exercising its spending power. ${ }^{105}$

\footnotetext{
2011).

98. See Flast v. Cohen, 392 U.S. 83, 101 (1968) (discussing the difficulty in determining whether a taxpayer has enough personal stake in the outcome of a tax provision to establish standing).

99. 262 U.S. 447 (1923).

100. Id. at 487 .

101. See id.

102. 392 U.S. at 103

103. Id. at 85,103 (putting in cite for the fact federal funds being distributed to religious schools).

104. Id. at 101

105. See infra Part III.A.2; see also Ariz. Christian Sch. Tuition Org. v. Winn, 131 S. Ct. 1436, 1447 (2011) (explaining that tax expenditures are not actually government spending under the tax and spend power); Hein v. Freedom from Religion Found., Inc., 551 U.S. 587, 608 (2007) (distinguishing between executive spending from President's discretionary fund and general government spending).
} 
2. Applying Flast to the Facts in Lew

The Flast Court recognized that to show standing, a taxpayer must demonstrate a "personal stake and interest" in the case in order for the court to have the ability to hear the taxpayer's case. ${ }^{106}$ The Court determined the taxpayer must establish a "logical nexus between the status asserted and the claim sought to be adjudicated."107 There are three important implications in Flast. First, Flast limits taxpayer standing to challenges that claim a federal tax is unconstitutional. ${ }^{108}$ Secondly, Flast requires a relationship between the taxpayer and the alleged unconstitutional tax. ${ }^{109}$ And third, the taxpayer must show a relationship between himself and the precise reason why the tax is unconstitutional. ${ }^{110}$ The Flast Court found this nexus because the taxing and spending power was being used "to favor one religion over another or to support religion in general."

As noted above, courts have continued to follow Flast in limiting the scope of taxpayer standing under the Establishment Clause. ${ }^{12}$ Taxpayer standing is limited to Establishment Clause cases that challenge the spending power of Congress. ${ }^{113}$ Thus, an Establishment Clause challenge to a tax credit does not have standing because it is not an exercise of government spending. ${ }^{114}$

The difference between government spending and a tax credit can quickly become confusing. Government spending can be defined as a "direct transfer of government (or public) revenues, generated by taxation, to the subsidized entity." 115 The Supreme Court has rejected the argument that a tax exemption is government spending. ${ }^{116}$ The taxpayers in Arizona Christian School Tuition Organization v. Winn argued that a "taxpayer's entire income is government property that becomes his own only when the government decides not to exercise its

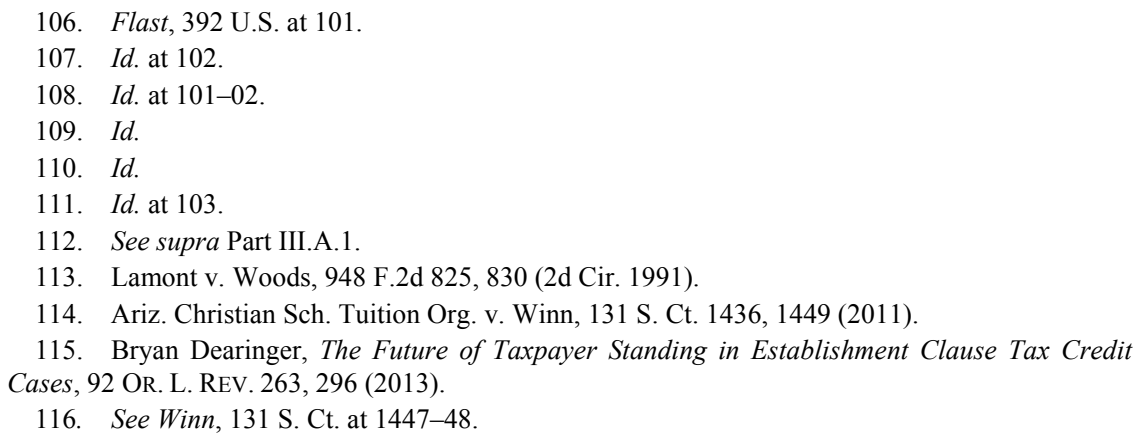


taxation power over $100 \%$ of it." ${ }^{117}$ This argument relies on the assumption that tax expenditure analysis is a form of government spending.

Tax expenditure analysis is the concept that the government loses money through tax exemptions, exclusions, and deductions. ${ }^{118}$ Therefore, the government "expends" money by allowing taxpayers to claim tax exemptions and tax deductions. One example is the proposed theory of the taxpayers in Winn. ${ }^{119}$ The theory is that the government owns $100 \%$ of a taxpayer's earnings and income. The government is entitled to all of that money, and when it allows the taxpayer to keep that money through a tax exclusion, tax deduction, or tax credit, the government is expending money to which it was otherwise entitled. The Court in Winn rejected the argument that a tax expenditure was a form of government spending. ${ }^{120}$ Therefore, for the government to exercise its spending power the government must actually transfer actual revenue or funds to an entity; there is no government spending if the government simply refuses to collect certain taxes. ${ }^{121}$

The reason why government spending is treated differently than tax credits or exclusions is a very subtle distinction. The Court in Winn explained the distinction as follows:

It is easy to see that tax credits and governmental expenditures can have similar economic consequences, at least for beneficiaries whose tax liability is sufficiently large to take full advantage of the credit. Yet tax credits and governmental expenditures do not both implicate individual taxpayers in sectarian activities. A dissenter whose tax dollars are "extracted and spent" knows that he has in some small measure been made to contribute to an establishment in violation of conscience. In that instance the taxpayer's direct and particular connection with the establishment does not depend on economic speculation or political conjecture. The connection would exist even if the conscientious dissenter's tax liability were unaffected or reduced. When the government declines to impose a tax, by contrast, there is no such connection between dissenting taxpayer and alleged establishment. Any financial injury remains speculative. ${ }^{122}$

117. Dearinger, supra note 115, at 298.

118. Michael J. Graetz \& Deborah H. Schenk, Federal Income TaXation: Principles AND POLICIES 39 (Rev. 4th ed. 2002).

119. See Dearinger, supra note 115, at 296 n.154.

120. Id.

121. Id.

122. Ariz. Christian Sch. Tuition Org. v. Winn, 131 S. Ct. 1436, 1447 (2011) (emphasis added) (internal citations omitted). 
In the facts of Lew, for the FFRF to have standing under the Flast test, the FFRF must establish a "logical nexus between the status asserted and the claim sought to be adjudicated." 123 The FFRF could establish this nexus only by (1) establishing a logical link between their status as taxpayers and the type of legislative enactment attacked; ${ }^{124}$ and (2) by establishing a nexus between that status as a taxpayer and the precise nature of the constitutional infringement. ${ }^{125}$

One interpretation of the Flast test is that a taxpayer may have standing in an Establishment Clause case when the "taxpayer's pocketbook harm implicates his conscience rights in a way that particularizes his personal stake as one who is compelled by the government to relinquish the protections afforded by the Establishment Clause." 126 This means that a taxpayer has to be taxed actual money, the government must spend the money in a way that is against the taxpayer's beliefs, and that spending must violate the Constitution. ${ }^{127}$

Under this interpretation of the Flast test, the FFRF fails to prove an injury in fact. Although the tax exemptions to "ministers of the gospel" may violate the taxpayers' consciences, the government is not actually expending any money in granting the exemption. This is where Lew can be distinguished from Flast. In Flast, federal funds were "being used to support religious schools in violation of the First Amendment."128 Unlike the federal funds in Flast, the Minister's Housing Allowance only grants a tax exclusion-it does not transfer actual government funds to "ministers of the gospel." "29 Therefore, the FFRF fails the Flast test and cannot establish standing under the Establishment Clause because there are no government expenditures actually granted through the Minister's Housing Allowance.

\section{Establishing Standing through an Equal Protection Analysis}

An alternative to taxpayer standing can be found in equal protection analysis. An injury in fact in an equal protection case may be the "denial

\footnotetext{
123. Flast v. Cohen, 392 U.S. 83, 102 (1968).

124. Id. at 102 .

125. Id.

126. See Dearinger, supra note 115 , at 285.

127. Id

128. Id. at 277 .

129. The text of the Minister's Housing Allowance states: "gross income does not include ...." 26 U.S.C. 107 (2012). Therefore, the government is not actually distributing money to the minister; rather, the minister is holding back money from the government.
} 
of equal treatment resulting from the imposition of [a] barrier, not the ultimate inability to obtain the benefit." ${ }^{130}$ In Northeastern Florida Chapter of Associated General Contractors of America v. City of Jacksonville, the Supreme Court stated:

When the government erects a barrier that makes it more difficult for members of one group to obtain a benefit than it is for members of another group, a member of the former group seeking to challenge the barrier need not allege that he would have obtained the benefit but for the barrier in order to establish standing. ${ }^{131}$

The Court in City of Jacksonville was not examining a tax issue, but its treatment of equal protection analysis in a standing issue is helpful. The city of Jacksonville, Florida enacted an ordinance that required 10\% of city revenue spent on city contracts to be set aside each year for "Minority Business Enterprises." 132 Minority Business Enterprises were businesses "whose ownership was at least $51 \%$ 'minority' or female."133 A general contractors' association whose membership consisted of many business owners who did not qualify as a Minority Business Enterprise owners brought suit against the city alleging the ordinance violated the Equal Protection Clause of the Fourteenth Amendment. ${ }^{134}$

The district court granted summary judgment for the general contractors, but the Eleventh Circuit reversed because the plaintiffs lacked standing. ${ }^{135}$ Specifically, the Eleventh Circuit stated that the plaintiffs had not shown that they would have received the city contracts even without the city ordinance. ${ }^{136}$ The Supreme Court reversed and held that plaintiffs did not have to show they would have won the city contracts to achieve standing, but instead that plaintiffs only needed to show they were denied equal protection for competing for the city contracts because of the barrier created by the city ordinance. ${ }^{137}$ Contextualizing City of Jacksonville with the Lew case would mean that plaintiffs Barker and Gaylor would not need to show that they would qualify for the Minister's Housing Allowance; rather, Barker and Gaylor

\footnotetext{
130. Ne. Fla. Chapter of Assoc. Gen. Contractors of Am. v. City of Jacksonville, 508 U.S. 656, 666 (1993).

131. Id.

132. Id. at 658 .

133. Id

134. Id. at 659 .

135. Id. at 660 .

136. Id

137. Id. at 666 .
} 
need only show that there is a significant government barrier barring them from obtaining the benefit.

Using an equal protection analysis, as applied by the Supreme Court in City of Jacksonville, the FFRF can argue they have suffered an injury in fact because they are denied Equal Protection because they cannot claim the Minister's Housing Allowance. Section 107(2) certainly seems to be a barrier erected by the government that only allows "ministers of the gospel" to claim the tax exclusion. ${ }^{138}$ Whether or not the individual plaintiffs would qualify for the exemption is not the dispositive issue. Instead, the individual plaintiffs only need to show that they are denied the Equal Protection of the Fourteenth Amendment based on religion, because only those who are religious may claim the tax exclusion under $\S 107(2)$.

\section{The Court's Analysis in Lew}

Although more subtle than the Court's application in City of Jacksonville, this is the analysis Judge Crabb applied in Lew, explaining that, "Gaylor's and Barker's alleged injury is the unequal treatment they receive under $\S 107(2) . " 139$ It is important to note here that the issue was not that the plaintiffs are atheists; the important aspect is that as employees for a non-religious non-profit, they are denied equal protection because the exemption is only available for employees of religious organizations.

The defendants in Lew argued that the FFRF lacked standing because they did not suffer an actual injury in fact because they did not try to claim the exemption from the IRS. ${ }^{140}$ Judge Crabb rejected defendants' argument, declaring that "there is no plausible argument that the individual plaintiffs could qualify for an exemption as 'ministers of the gospel,' so it would serve no legitimate purpose to require plaintiffs to claim the exemption and wait for the inevitable denial of the claim."

Defendants claimed that the individual plaintiffs could have qualified for the exemption as "ministers of the gospel" had they attempted to qualify for the exemption. ${ }^{142}$ Relying on a prior Seventh Circuit opinion, defendants argued that an atheist group could qualify as a religion under

\footnotetext{
138. 26 U.S.C. 107(2) (2012).

139. Freedom from Religion Found., Inc. v. Lew, 983 F. Supp. 2d 1051, 1054 (W.D. Wis. 2013), vacated, 773 F.3d 815 (7th Cir. 2014).

140. Id. at 1055 .

141. Id. at $1055-56$.

142. Id. at 1055 .
} 
the Constitution. ${ }^{143}$ In Kaufman v. McCaughtry, the Seventh Circuit held that a prisoner's rights were violated because he was not allowed to start an atheist study group in prison. ${ }^{144}$

The Kaufman court stated that "[a] religion need not be based on a belief in the existence of a supreme being (or beings, for polytheistic faiths) ... nor must it be a mainstream faith." ${ }^{\text {"145 }}$ Instead, a religion may be found when any person has sincerely held beliefs "dealing with issues of "ultimate concern"" that occupy "a "place parallel to that filled by ... God in traditionally religious persons.", 146

Relying on Kaufman, the defendants in Lew argued that the plaintiffs Barker and Gaylor, in their individual capacity, could qualify for the Minister's Housing Allowance because their atheism could qualify them as practicing a religion. ${ }^{147}$ Judge Crabb rejected this argument and focused on whether the plaintiffs Barker and Gaylor could qualify as "ministers of the gospel" according to the text of the statute. ${ }^{148}$

Courts have created a five-factor test to determine whether a person qualifies as a "minister of the gospel." A person may qualify as a minister of the gospel if that person:

(1) performs sacerdotal functions under the tenets and practices of the particular religious body constituting his church or church denomination; (2) conducts worship services; (3) performs services in the control, conduct, and maintenance of a religious organization that operates under the authority of a church or church denomination; (4) is ordained, commissioned, or licensed and (5) is considered to be a spiritual leader by his religious body. ${ }^{14}$

Defendants in Lew argued that some actions by plaintiffs Gaylor and Barker met the requirements of the test. ${ }^{150}$ For example, defendants argued that "Barker engages in a number of activities that could be classified as sacerdotal, such as performing de-baptisms, lecturing, performing marriages, counseling, promoting free thought and writing free thought songs." ${ }^{151}$ Judge Crabb found that, while some of Barker

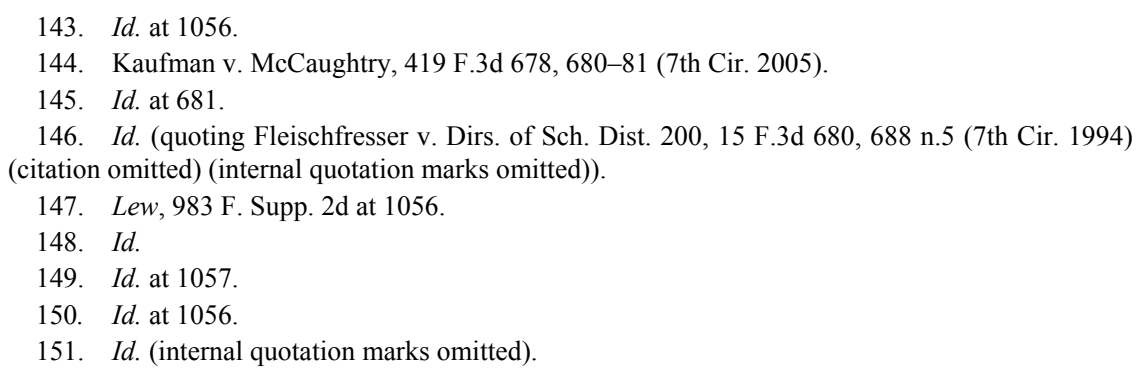


and Gaylor's actions might meet some of the criteria of a "minister of the gospel," there was no evidence to prove that either of the plaintiffs could qualify as a "minister of the gospel."152

Judge Crabb referred to defendants' arguments as "red herrings." 153 Indeed, defendants' arguments miss the point. The FFRF was not challenging the validity of the Minister's Housing Allowance from their beliefs as atheists; rather, the FFRF was alleging unequal tax treatment because they were employees of a non-profit and could not gain the tax exclusion because of their employee status rather than their religious (or lack of religious) beliefs. ${ }^{154}$

This is a subtle, yet very important distinction. The FFRF was not alleging that their injury was the violation of their beliefs as atheists, nor were they alleging they could not receive the tax exclusion because of their beliefs as atheists. Instead, plaintiffs were arguing that the Minister's Housing Allowance is unconstitutional because it grants the exclusion for housing allowances only for "ministers of the gospel." 155 Gaylor and Barker's injuries stem from the fact that both are employed at a non-profit organization and portions of their salaries are designated as housing allowances, ${ }^{156}$ yet they cannot claim the exemption because their work as employees does not qualify as the kind of work that qualifies them as "ministers of the gospel" under the statute.

It was this unequal treatment for non-profit employees at issue- - both in the standing issue and the merits issue - and not the atheist beliefs of the FFRF that were central to Judge Crabb's finding of standing. ${ }^{157}$ The FFRF and individual plaintiffs had been injured by the unequal treatment of the tax code, their injury was traceable to the defendants who were tasked with implementing the tax code, and the FFRF's injury was redressable by finding the Minister's Housing Allowance unconstitutional and enjoining the enforcement of the Allowance. ${ }^{158}$ Using the central idea of City of Jacksonville, Barker and Gaylor's injuries stemmed from a significant barrier erected by the government that prevented them from obtaining the benefit. ${ }^{159}$

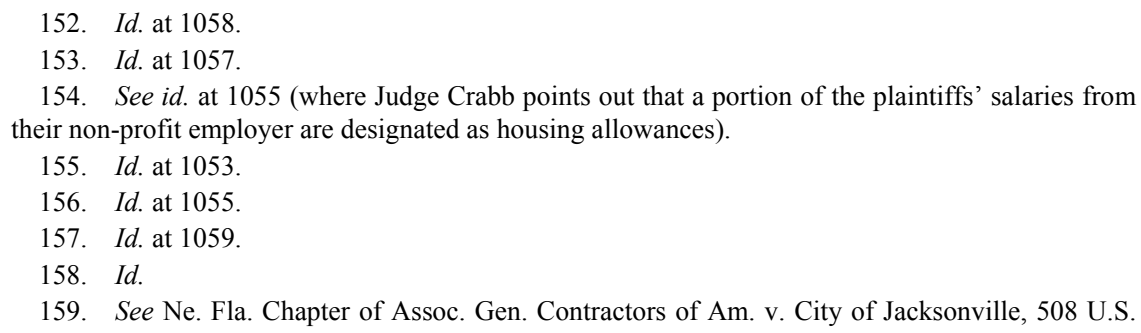


However, the Seventh Circuit rejected Judge's Crabb's conclusions. ${ }^{160}$ The Seventh Circuit's conclusion is really quite simplebecause the plaintiffs never claimed the Minister's Housing Allowance in their personal taxes, and because they were never denied the exemption, the plaintiffs suffered no injury. ${ }^{161}$ Circuit Judge Flaum wrote, "[w]ithout a request, there can be no denial.","162

In the opinion, the court first rejected the argument that the plaintiffs had standing as taxpayers because they were "similarly situated" to ministers. ${ }^{163}$ The court reasoned that even though the plaintiffs may be similarly situated to "ministers of the gospel," since they did not claim the exemption, they did not suffer a legally cognizable injury. ${ }^{164}$ The court went further to say that the key difference between a minister and the plaintiffs was that the ministers actually claimed the tax exclusion, where the plaintiffs neglected to do so. ${ }^{165}$ Therefore, according to the reasoning of the court, the only thing barring the plaintiffs bringing their claim to court was claiming the exclusion in their taxes. ${ }^{166}$

The court then rejected the argument that the Minister's Housing Allowance may be insulated from challenge because of the standing requirements. ${ }^{167}$ The court wrote, "'[t]he assumption that if [the plaintiffs] have no standing to sue, no one would have standing, is not a reason to find standing.","168

Circuit Judge Flaum next addressed Judge Crabb's argument that the plaintiffs should not have to claim the exemption because they would be inevitably denied. ${ }^{169}$ This issue is where Judge Flaum chose to devote the most attention to his critique of Judge Crabb's opinion. ${ }^{170}$ The court disagreed with both Judge Crabb and the Fourth Circuit, which both reasoned that requiring a plaintiff to claim a tax exemption they were sure to be denied in order to have standing would be "futile" and a

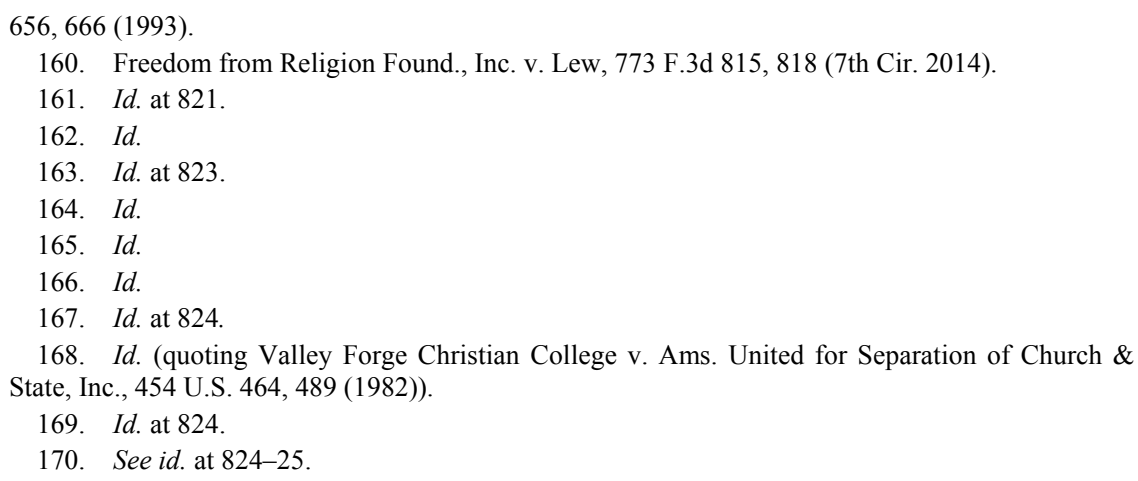


"waste of time.", Judge Flaum wrote, "Article III 'is not merely a troublesome hurdle to be overcome if possible so as to reach the 'merits' of a lawsuit which a party desires to have adjudicated; it is a part of the basic charter promulgated by the Framers.",172

The last aspect of Judge Crabb's opinion challenged by the Seventh Circuit was the argument that the Supreme Court has previously ruled on Establishment Clause issues when it was unclear whether the plaintiff had met the requirements of standing. ${ }^{173}$ An example is Walz v. Tax Commission of the City of New York, ${ }^{174}$ where the Supreme Court found that religious property exemptions did not violate the Establishment Clause when those same tax exemptions were also available to other educational and charitable non-profit organizations. ${ }^{175}$ In Walz, the Court did not raise the issue of standing. ${ }^{176}$ The Seventh Circuit noted that the fact that a previous case declined to address the issue of standing is not a basis to determine that the plaintiff in that case actually had standing. ${ }^{177}$

In the second paragraph of the opinion, Circuit Judge Flaum writes, "[w]e conclude that the plaintiffs lack standing to challenge $\S 107(2)$. We therefore do not reach the issue of the constitutionality of the parsonage exemption."178 This quote precisely demonstrates the difficulty that the standing issue poses upon those seeking to challenge the Minister's Housing Allowance. Because standing is so difficult to show, it is nearly impossible to get courts to "reach the issue" of the Minister's Housing Allowance. ${ }^{179}$ This quote also represents the issue presented by all standing challenges - courts can use standing to decline to decide difficult or controversial cases. ${ }^{180}$ Here, rather than addressing the merits of the FFRF's claim, the Seventh Circuit chose to rule on the

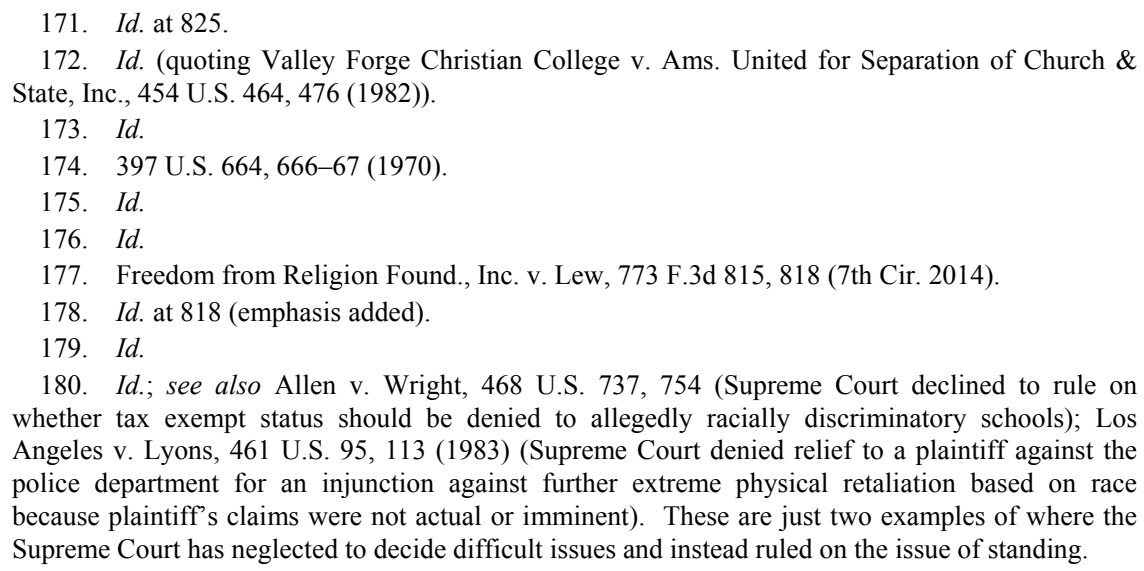
Angeles v. Lyons, 461 U.S. 95, 113 (1983) (Supreme Court denied relief to a plaintiff against the police department for an injunction against further extreme physical retaliation based on race because plaintiff's claims were not actual or imminent). These are just two examples of where the Supreme Court has neglected to decide difficult issues and instead ruled on the issue of standing. 
issue of standing and not "reach the issue of the constitutionality of the parsonage exemption." 181

Based upon the Seventh Circuit's opinion in Lew, and considering the narrowing trend of courts' willingness to grant taxpayer standing on Establishment Clause cases, it appears that the Minister's Housing Allowance is currently insulated from a challenge in court. ${ }^{182}$ If courts refuse to rule on the issue, the only option left is for Congress to change the text of the statute. Yet, it is hardly imaginable that a politician seeking reelection would choose to focus upon the issue of denying tax exemptions to ministers. Therefore, it appears, for the time being, that regardless of whether or not the Minister's Housing Allowance violates the Constitution of the United States, the Minister's Housing Allowance will remain because it cannot be challenged in court.

\section{B. The Merits of the Case}

Although the Seventh Circuit reversed the district court and declined to reach the merits of the Establishment Clause issue in Lew because of standing, it is the primary purpose of this Comment to show how the Minister's Housing Allowance violates the Constitution. The essential issue is whether a tax exemption granted exclusively to "ministers of the gospel" runs afoul of the Establishment Clause. The remaining portion of this Comment will argue that, regardless of standing, the Minister's Housing Allowance violates the Establishment Clause because (1) it does not have a secular purpose; (2) it can be reasonably seen as a government endorsement of religion; (3) it fosters excessive entanglement between government and religion; (4) it is not rooted in an historical tradition; and (5) it violates government neutrality with religion. Although Judge Crabb's analysis in Lew focused primarily on the first three factors, ${ }^{183}$ this Comment also examines the historical test and the neutrality test to show that the Minister's Housing Allowance cannot withstand any of the tests articulated by Supreme Court precedent.

The First Amendment states, "Congress shall make no law respecting an establishment of religion, or prohibiting the free exercise thereof." 184 The "Religion Clauses" of the First Amendment have

181. 773 F.3d at 818

182. See supra Part III.A.1 (discussing the history of taxpayer standing in federal courts).

183. Lew, 983 F. Supp. 2d 1051, 1060 (W.D. Wis. 2013), vacated, 773 F.3d 815 (7th Cir. 2014).

184. U.S. CONST. amend. I, $\S 1$. 
developed different theories and bodies of law for both the Establishment Clause and the Free Exercise Clause.

To determine whether the Minister's Housing Allowance violated the Establishment Clause, Judge Crabb applied a version of the Lemon Test. ${ }^{185}$ The Lemon Test was first articulated by the Supreme Court in Lemon v. Kurtzman. ${ }^{186}$ A government action violates the Establishment Clause if it fails any one of the three prongs of the test. ${ }^{187}$ "Under Lemon, government action violates the [E]stablishment [C]lause if (1) it has no secular purpose; (2) its primary effect advances or inhibits religion; or (3) it fosters an excessive entanglement with religion."188

Although there are many tests the Supreme Court has employed in religion cases, the Lemon Test is often used, and it is the test the Seventh Circuit applied in other cases. ${ }^{189}$ Despite how often the Lemon Test is used, it has received its share of criticism. ${ }^{190}$ Justice Scalia said of the Lemon Test that it is like:

a ghoul in a late-night horror movie that repeatedly sits up in its grave and shuffles abroad, after being repeatedly killed and buried. [It] is there to scare us [when] we wish it to do so, but we can command it to return to the tomb at will. When we wish to strike down a practice it forbids, we invoke it, when we wish to uphold a practice it forbids, we ignore it entirely.

In response to this criticism, in Lynch v. Donnelly, Justice O'Connor offered what is now known as the "modified Lemon Test."192 In the modified Lemon Test, the Court asks (1) whether the purpose of the government action endorses religion and (2) whether the statute actually conveys a message of endorsement. ${ }^{193}$ In Lew, Judge Crabb employed the modified Lemon Test but examined the issues under the traditional Lemon Test as well. ${ }^{194}$

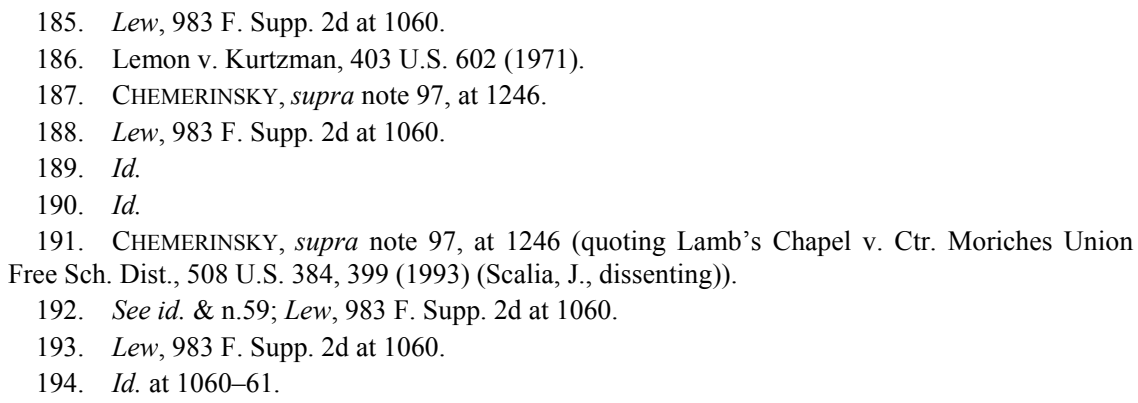


1. The Minister's Housing Allowance Has No Secular Purpose

The defendants in Lew argued that the purpose of the Minister's Housing Allowance was to eliminate "discrimination among different religions and between religious and nonreligious persons." Defendants argued that Congress, in response to the Convenience of the Employer Doctrine (which allows employees required to live on business premises to exclude housing from their gross income), ${ }^{196}$ passed a corresponding tax code for ministers that eventually became $\S 107(1)$ the Parsonage Exemption. ${ }^{197}$ The exemption under $\S 107(1)$ benefits ministers of religious organizations that provide housing, but it is of no benefit to ministers whose church or organization does not provide housing. Defendants argued that when Congress passed $\S 107(2)$, they were attempting to answer just such a question. ${ }^{198}$

Defendants' argument was that by passing the Minister's Housing Allowance, Congress was not endorsing religion; ${ }^{199}$ instead, Congress was removing religious discrimination because now all ministers could enjoy the exemption of housing regardless of whether their employer or religion provided housing. ${ }^{200}$ The Minister's Housing Allowance, according to the defendants, places all ministers on a level playing field.

Judge Crabb ultimately rejected the arguments of the defendants, stating that the purpose of the Minister's Housing Allowance "was to assist a subset of religious groups, which ... is not a secular purpose under the [E]stablishment [C]lause." ${ }^{201}$ She reasoned that the Parsonage Exemption discriminates against certain ministers no more than secular employees who purchase their own housing and are excluded from claiming the convenience of the employer tax exclusion. ${ }^{202}$

Judge Crabb rejected the defendants' argument that the Minister's Housing Allowance eliminated any discriminatory effect of the Parsonage Exemption. ${ }^{203}$ "[T]o the extent that $\S 107(1)$ discriminates among religions, $\S 107(2)$ does not eliminate that discrimination but

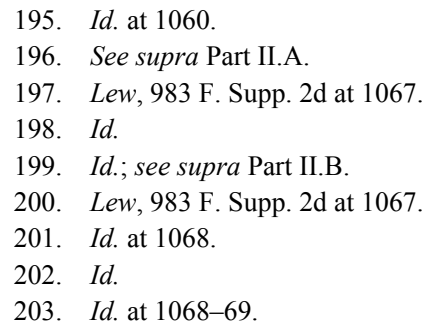


merely shifts it." ${ }^{204}$ Here the court relied on Erwin Chemerinksy, ${ }^{205}$ the founding Dean at the University of California, Irvine School of Law and considered an expert in the field of constitutional law. ${ }^{206}$ In his 2003 article, Chemerinsky argues that the Minister's Housing Allowance in $\S 107(2)$ discriminates against those religions that do not have clergy. ${ }^{207}$ "[S]ection $\S 107(2) \ldots$ offers a huge financial benefit to those religions and churches that have clergy as compared to those which do not."208 Furthermore, Chemerinsky argues that the Minister's Housing Allowance discriminates in other ways as well. ${ }^{209} \mathrm{He}$ argues that the exemption discriminates against new religions which may not be "affiliated with a national church or which do not have a history of ordaining ministers." $" 210$

Chemerinsky's critique of the lack of secular purpose in $\S 107(2)$ does not stop there; Chemerinsky notes that the IRS tax guide for churches "discriminates among clergy based on the specific tasks they are performing." 211 The tax guide has certain criteria that a minister has to meet in order to claim the tax exclusion. ${ }^{212}$ As explained above, tax courts have noted five factors considered in determining whether a person is a "minister of the gospel." 213 Therefore, a minister who performs services for his church may be unable to claim the Minister's Housing Allowance if he does not perform sacerdotal functions or conduct worship services (or meet the other criteria of the test). ${ }^{214}$

For example, consider a minister whose primary responsibility is counseling and is employed by a very large church with a large staff. The counseling minister counsels on a daily basis, but the minister never performs sacerdotal functions in a Sunday service, such as baptism or communion. The minister never preaches or leads the congregation, and unless the individual members go to counseling, the members might not know anything about the minister. Such a counseling minister, although

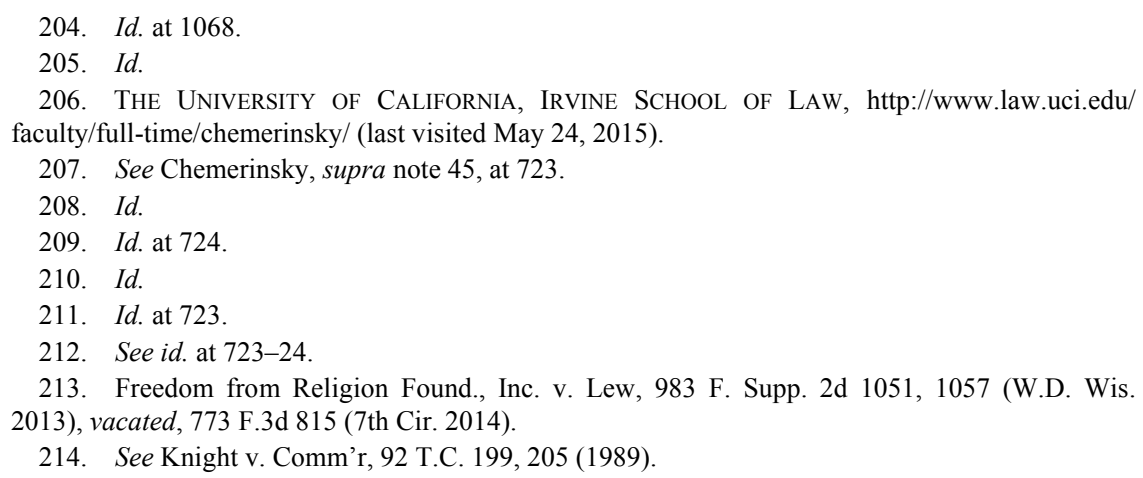


their services are essential to the church, would not meet the criteria of a "minister of the gospel." 15 Such an example is why Chemerinsky reasons that the Minister's Housing Allowance "discriminates against religions in so many ways that it undermines any claim that it is justified as a way of treating religions equally." 216

Under Judge Crabb's reasoning, even if the Minister's Housing Allowance cured any discrimination within religious groups, the statute would still violate the Establishment Clause because "the provision applies to religious persons only." 217 The court noted the facial lack of a secular purpose, stating that "[a] desire to assist disadvantaged churches and ministers is not a secular purpose and it does not produce a secular effect when similarly disadvantaged secular organizations and employees are excluded from the benefit." 218

Defendants argued that other provisions in the tax code granting exemptions to other nonreligious groups justified the Minister's Housing Allowance. $^{219}$ Defendants noted exclusions for members of the military, citizens who live abroad, and federal employees who live abroad. ${ }^{220}$ Citing Texas Monthly, ${ }^{221}$ the court noted that an exemption that was granted to a wide range of nonreligious groups could survive a constitutional challenge, but it was not enough to point to a "small number of secular groups" to survive a constitutional challenge. ${ }^{222}$

Ultimately, Judge Crabb ruled that the Minister's Housing Allowance did not have a secular purpose; rather, the statute would appear to the "reasonable observer" to be an endorsement of religion. ${ }^{223}$ Although case law is limited on this issue, the district court's reasoning in Lew corresponds with other decisions that partially address similar issues. $^{224}$

In a 2014 case in the Eastern District of Kentucky, plaintiffs filed suit challenging the Minister's Housing Allowance. ${ }^{225}$ Ultimately, the court dismissed the plaintiff's claim for lack of standing, but the court

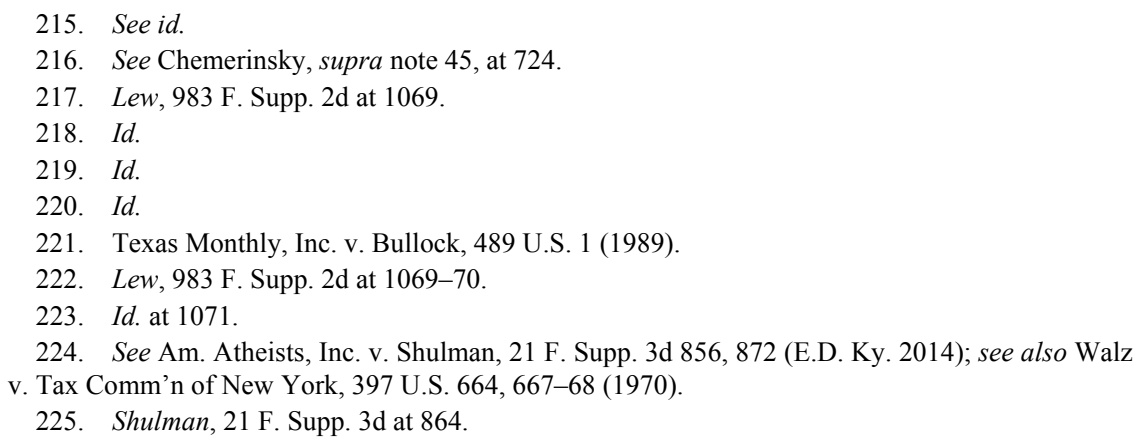


noted that a challenge to the Minister's Housing Allowance is at least plausible enough to successfully survive a motion to dismiss. ${ }^{226}$ This means that the plaintiffs had established a plausible claim for which relief could be granted. ${ }^{227}$

The Supreme Court's opinion in Walz v. Tax Commissioner of New York is perhaps the most helpful case in examining the secular purpose and effects of the Minister's Housing Allowance. ${ }^{228}$ The Court in Walz upheld a New York statute granting tax exemptions to churches because the exemption was also available to nonreligious charities and nonprofits. ${ }^{229}$ The Walz Court gave a lengthy and useful analysis of the original intent of the Religious Clauses in the First Amendment. ${ }^{230}$

Writing in Walz, Chief Justice Burger reasoned that maintaining a separation between promotion of religion and neutrality is difficult because the "very existence of the Religion Clauses is an involvement of sorts." 231 Burger also noted that granting tax exemptions for churches is an "unbroken practice" from the time the Constitution and Bill of Rights was written and those exemptions are "not something to be lightly cast aside." 232 The Court's reliance on a long legislative history seems, at first, to favor the view that the Minister's Housing Allowance does not violate the Establishment Clause. If the nation has a long history of granting tax exemptions to religious organizations, then extending those exemptions to the leaders of those organizations may be justified as well.

However, this reasoning can quickly be dispelled by examining the legislative history of the Minister's Housing Allowance. While tax exemptions for religious organizations can trace its roots back centuries, tax exemptions for ministers is a relatively recent inclusion into the law. ${ }^{233}$ First, the Minister's Housing Allowance was not included in the tax code until $1954 .{ }^{234}$ Second, Representative Mack's statements that the law should be passed for those "who are caring for our spiritual welfare" during "times when we are being threatened by a godless and

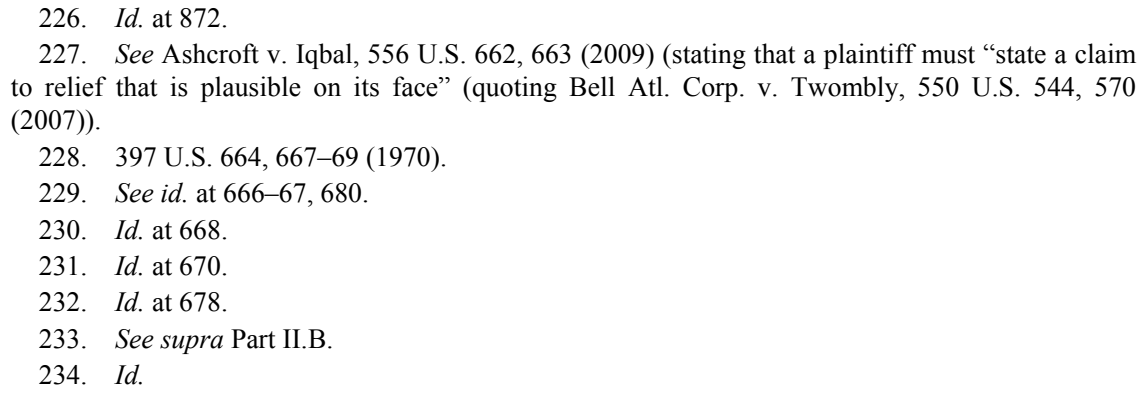

227. See Ashcroft v. Iqbal, 556 U.S. 662, 663 (2009) (stating that a plaintiff must "state a claim to relief that is plausible on its face" (quoting Bell Atl. Corp. v. Twombly, 550 U.S. 544, 570

228. 397 U.S. 664, 667-69 (1970).

229. See id. at 666-67, 680.

230. Id. at 668 .

231. Id. at 670 .

232. Id. at 678 .

233. See supra Part II.B.

234. Id. (2007)). 
anti-religious world movement" are important to understand Congress's purpose for enacting $\S 107(2) .{ }^{235}$ Given these statements, it seems that the congressional intent of $\S 107(2)$ was to promote and endorse religion. According to Burger, the legislative purpose for an act must be "neither the advancement nor the inhibition of religion; it is neither sponsorship nor hostility."236

Leaning on Burger's analysis in Walz, the Minister's Housing Allowance violates the Establishment Clause because it lacks a secular purpose. The legislative history is quite clear that the intent of Congress was to advance, or at least, endorse religion. Applying the modified Lemon Test, the Minister's Housing Allowance has no secular purpose and it conveys an actual message of endorsement to the general observer. $^{237}$

\section{The Effect of the Minister's Housing Allowance Endorses Religion}

The second prong of the modified Lemon Test requires that a law must not have the primary effect of advancing or inhibiting religion to withstand an Establishment Clause challenge. ${ }^{238}$ In Texas Monthly, Inc. v. Bullock, the Supreme Court was faced with the issue of whether state tax exemptions for religious periodicals violated the Establishment Clause. ${ }^{239}$ The Texas law exempted " "[p]eriodicals that are published or distributed by a religious faith and that consist wholly of writings promulgating the teaching of the faith and books that consist wholly of writings sacred to a religious faith.", 240 As is clear from the text of the statute, the exemption was exclusively granted to religious publications. ${ }^{241}$ Texas Monthly was a general interest magazine that was not exclusively a religious magazine. ${ }^{242}$ In a plurality opinion, the Court ultimately decided, "when confined exclusively to publications advancing the tenets of a religious faith, the exemption runs afoul of the

\footnotetext{
235. Freedom from Religion Found., Inc. v. Lew, 983 F. Supp. 2d 1051, 1067 (W.D. Wis. 2013), vacated, 773 F.3d 815 (7th Cir. 2014) (quoting General Revenue Revision: Hearings Before the H. Comm. On Ways and Means, 83rd Cong. 1574-75 (1953) (statement of Peter F. Mack, Jr.)).

236. Walz, 397 U.S. at 672.

237. See Lew, 983 F. Supp. $2 \mathrm{~d}$ at 1071.

238. Id. at 1060 .

239. Texas Monthly, Inc. v. Bullock, 489 U.S. 1, 5 (1989).

240. Id. (quoting TEX. TAX CODE ANN. § 151.312 (West 1982)).

241. Id.

242. Id. at 6 .
} 
Establishment Clause ...."243 The Court in Texas Monthly addressed a few aspects that had an important bearing upon the decision in Lew.

First, the Court noted the difficulty in avoiding overlap between government interests and those of religious interests:

The nonsectarian aims of government and the interests of religious groups often overlap, and this Court has never required that public authorities refrain from implementing reasonable measures to advance legitimate secular goals merely because they would thereby relieve religious groups of costs they would otherwise incur. ${ }^{244}$

Effectively, the Court noted that government policies that incidentally benefit religion are not automatically invalid. ${ }^{245}$ The Court went on to hold that tax benefits enjoyed by religious organizations do not violate the Establishment Clause if such benefits also "flow[] to a large number of nonreligious groups as well." 246

Secondly, the Court addressed whether there was a real difference between a tax subsidy and a tax exemption. ${ }^{247}$ The Court stated, "[e]very tax exemption constitutes a subsidy that affects nonqualifying taxpayers, forcing them to become "indirect and vicarious donors." 248 The court in Lew relied upon this reasoning. ${ }^{249}$ The Court in Texas Monthly noted that exemptions act as a subsidy and when the government subsidizes a religious group via an exemption this will often be viewed as endorsing religion or a religious group. ${ }^{250}$

Judge Crabb relied heavily upon Texas Monthly in Lew because it is one of the few existing cases nearly on point. ${ }^{251}$ The Minister's Housing Allowance is comparable to the Texas tax exemption because both are only available to religious persons or entities. Applying the rationale from Texas Monthly, it is clear that the Minister's Housing Allowance has the effect of endorsing religion "because the exemption provides a benefit to religious persons and no one else." ${ }^{252}$ If the effect of the Minister's Housing Allowance endorses religion, then the tax exemption

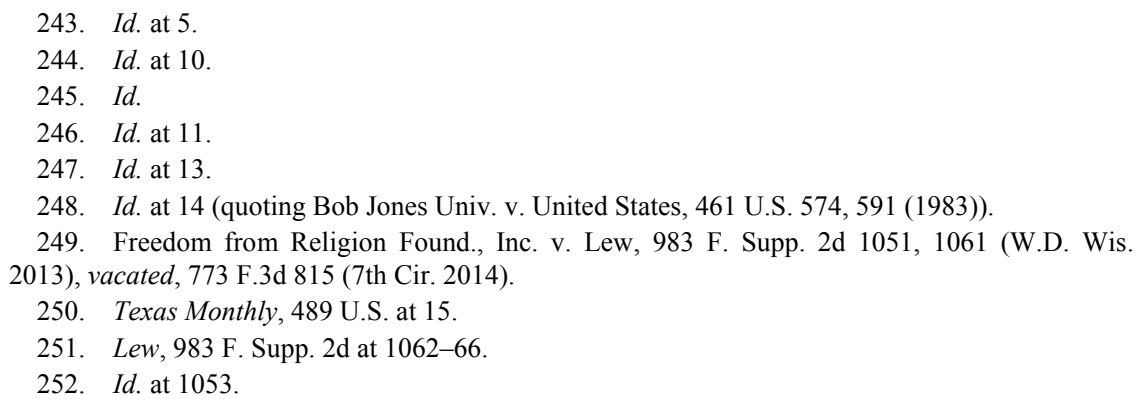


violates the Establishment Clause. ${ }^{253}$ However, if the Minister's Housing Allowance were available to other non-religious persons, such as directors of non-profit organizations, then, under Walz, the Allowance would not run afoul of the Constitution. But this is not the case. Because the Minister's Housing Allowance is granted solely to religious persons, the Allowance has the effect of endorsing religion and violates the Establishment Clause.

\section{The Minister's Housing Allowance Fosters Excessive Entanglement}

Although Judge Crabb relied on the two factors in the modified Lemon Test, she also used the third factor of the original Lemon Test, which finds a law unconstitutional if it fosters excessive entanglement between church and state. ${ }^{254}$ The Court noted that Texas Monthly was a closely analogous case. ${ }^{255}$ The Court in Texas Monthly held that the Texas law granting tax exemptions exclusively to religious publications fostered excessive entanglement because it required the government to "evaluat $[\mathrm{e}]$ the relative merits of differing religious claims." 256

The Minister's Housing Allowance necessarily requires this evaluation of relative merits because it is not easily discernable who is a "minister of the gospel" according to the plain text of $\S 107(2)$. The courts have developed a five factor test to determine whether a person is a minister and able to claim the exclusion under 107(2). ${ }^{257}$ The factors are whether the individual:

(1) performs sacerdotal functions under the tenets and practices of the particular religious body constituting his church or denomination, (2) conducts worship services, (3) performs services in the control, conduct, and maintenance of a religious organization, (4) is ordained, commissioned, or licensed, and (5) is considered to be a spiritual leader by his religious body. ${ }^{25}$

Similar factors are set forth in the Tax Regulations. ${ }^{259}$

Because of Congress's failure to define "minister of the gospel" in

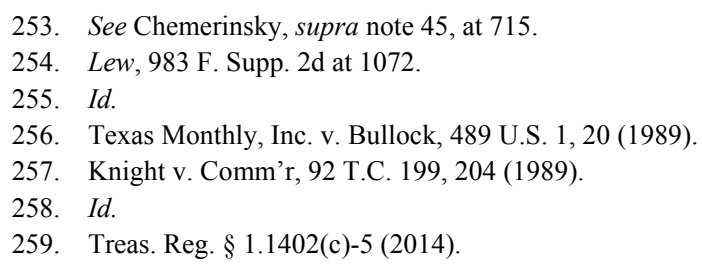


$\S 107$, all three branches of the government become entangled in religion. First, Congress grants the exemption that is codified in $\S 107$. Because of the ambiguity of the exemption, the Internal Revenue Service (IRS) must determine who qualifies as a minister of the gospel. ${ }^{260}$ The IRS is an extension of the executive branch tasked with "interpreting, administering, and enforcing the federal tax statutes." ${ }^{261}$ Therefore, from the outset, both the executive and legislative branches of government are entangled in religion because the executive is now tasked with interpreting and enforcing the legislation exempting an ambiguous class of citizens based on religion.

However, because disputes arise while interpreting who qualifies as a "minister of the gospel," the judicial branch must decide these disputes. Judges must look at the actions of the individual and the tenets and practices of the religious organization to determine whether the individual qualifies for the exemption. ${ }^{262}$ The determination of whether a person is a minister of the gospel is a fact and circumstances analysis, which looks to the type and characterization of the organization in combination with the nature of the ministerial duties. ${ }^{263}$ The complications of this fact-intensive analysis are clear from Lew and another case where the Tax Court was seeking to define "minister of the gospel." 264 In Knight v. Commissioner, the court considered whether the taxpayer who was licensed but not ordained as a minister was eligible for a tax exclusion for his ministerial wages. ${ }^{265}$ The Knight court examined the constitution of the religious denomination and weighed the duties and services of the taxpayer, and ultimately the court determined that although the taxpayer did not meet all five factors, his work could be classified as a minister. ${ }^{266}$ Certainly there is an entanglement issue when the government is examining a denomination's constitution as well as looking at the daily services performed by one of its ministers.

Judge Crabb stopped short of making a determination about whether the Parsonage Exemption fostered excessive entanglement, ${ }^{267}$ but the court's brief treatment of the subject as well as an examination of Knight

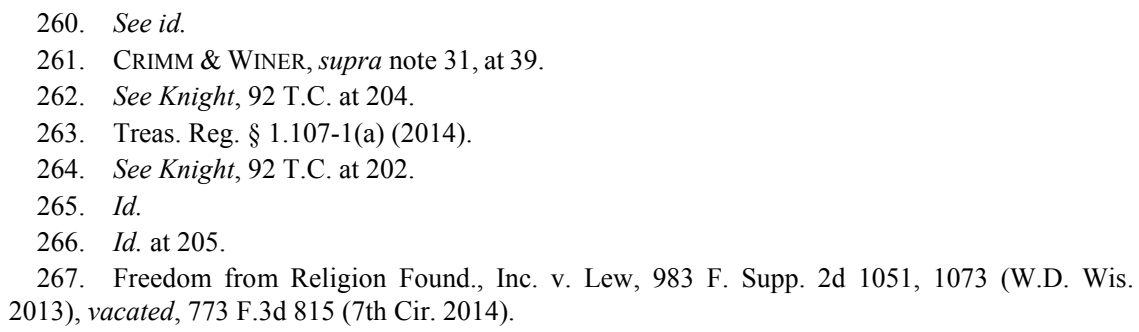


certainly leans heavily in favor of a finding of excessive entanglement. ${ }^{268}$ Due to the unclear language of "ministers of the gospel," both the executive branch (through the IRS) and the judiciary (through the courts) become entangled in religion because of the fact-intensive determination required in each applicant's case.

After examining the various prongs of the Lemon Test, it is clear that the Minister's Housing Allowance violates the Establishment Clause. A law violates the Establishment Clause if it fails any prong of the test. ${ }^{269}$ The Minister's Housing Allowance fails the modified Lemon Test because the legislative history is clear that the purpose of the exemption was to endorse religion, and the message of endorsement is clear to a reasonable observer. ${ }^{270}$

The Minister's Housing Allowance also fails the third prong of the original Lemon Test because it fosters excessive government entanglement with religion by requiring the IRS and the courts to examine ministers' daily duties as well as religious by-laws of particular denominations. ${ }^{271}$ Therefore, regardless of what version of the Lemon Test is applied to the Minister's Housing Allowance, the Minister's Housing Allowance violates the Establishment Clause.

\section{The Minister's Housing Allowance Fails the Historical Test}

Besides the Lemon Test, the Supreme Court has employed other tests in Establishment Clause cases. One of these tests is the historical test. Under the historical test, a government action may survive an Establishment Clause challenge if it is rooted in an historical tradition. ${ }^{272}$

In a 2014 case, Town of Greece v. Galloway, the Supreme Court reversed the Second Circuit's ruling that a prayer before a town's board meetings violated the Establishment Clause. ${ }^{273}$ Justice Kennedy, writing for a majority, stated that the prayers before the town's board meetings did "not fall outside the tradition this Court has recognized." "274

Although the issue in Town of Greece was prayer, the case could prove to be a strong support for the tax issue in Lew. In Town of Greece, a New York town supervisor decided in 1999 to begin town board

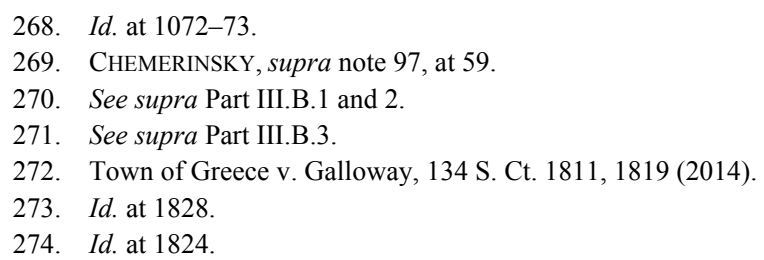


meetings by inviting members of the local clergy to deliver an invocation. ${ }^{275}$ The district court ruled in favor of the town, finding that the prayer did not run afoul of the Establishment Clause. ${ }^{276}$ The Second Circuit reversed, holding that "aspects of the prayer program, viewed in their totality by a reasonable observer, conveyed the message that Greece was endorsing Christianity." ${ }^{277}$ The issue, as framed by the Supreme Court, was "whether the prayer practice in the town of Greece fits within the tradition long followed in Congress and the state legislatures."278

The Court relied on their decision in Marsh v. Chambers, which held that applying other tests usually applied in Establishment Clause cases was "unnecessary because history supported the conclusion that legislative invocations are compatible with the Establishment Clause."279 In Town of Greece, the Court looked at the long history of opening legislative sessions with prayer. ${ }^{280}$ The Court noted that prayer before legislative meetings can trace its history back to at least the first Congress. $^{281}$

Justice Kennedy, relying on Marsh, stated "it is not necessary to define the precise boundary of the Establishment Clause where history shows that the specific practice is permitted."282 Kennedy held that the prayers before the town's meetings "[did] not fall outside the tradition this Court has recognized." 283 Kennedy later wrote:

The prayer opportunity in this case must be evaluated against the backdrop of historical practice. As a practice that has long endured, legislative prayer has become part of our heritage and tradition, part of our expressive idiom, similar to the Pledge of Allegiance, inaugural prayer; or the recitation of 'God save the United States and this honorable Court' at the opening of [the Supreme] Court's sessions. ${ }^{284}$

Although Lew is not a case about prayer before legislative sessions, and though the tax exemptions granted to individual ministers under

\footnotetext{
275. Id. at 1816.

276. Id. at 1817 .

277. Id. at 1818 .

278. Id. at 1819.

279. Id. at 1818 .

280. Id. at 1819 .

281. Id.

282. Id. (emphasis added).

283. Id. at 1824 .

284. Id. at 1825 .
} 
$\S 107(2)$ cannot be traced back to the founding fathers, the argument can certainly be made that tax benefits granted on the basis of religion have roots that can be traced back to the Founding Fathers. ${ }^{285}$ As the Court noted in Walz, Congress has recognized real estate tax exemptions for religious bodies tracing back to the "earliest days" of the Constitution. ${ }^{286}$ The Walz Court noted a number of historical tax exemptions for religious organizations for both real and personal property. ${ }^{287}$ However, the Minister's Housing Allowance is a federal income tax exemption, and tax exemptions from federal income taxes do not have an historical and rooted tradition. ${ }^{288}$

The federal income tax was first promulgated in 1913, and the Minister's Housing Allowance was not a part of the original tax code. ${ }^{289}$ As noted above, defendants in Lew argued that the Minister's Housing Allowance was enacted in order to cure discrimination between religions created by the Parsonage Exemption. ${ }^{290}$ Under this argument, the Minister's Housing Allowance seeks to protect the traditional property exemption recognized in the early years of the nation by allowing ministers to exempt their housing even if that housing is not owned by the religious institution and provided to the minister as part of their compensation.

Using the argument that the Allowance is a slight variation on the traditional practice of tax exemptions for religions for real property, it is possible to draw analogies to Town of Greece. Like the prayer in Town of Greece, the exemption in $\S 107(2)$ is available to all religions and not reserved exclusively for Christian ministers. ${ }^{291}$ City officials in Town of Greece stated that atheists could lead the town meeting invocations. ${ }^{292}$ Defendants in Lew argued that plaintiffs' claim of atheism did not disqualify them from the exemption. ${ }^{293}$ But once again, FFRF was not

\footnotetext{
285. See supra Part II.B.

286. Walz v. Tax Comm'n of New York, 397 U.S. 664, 677 (1970).

287. Id.

288. The first federal tax exclusions for ministers housing were not codified until the Revenue Act of 1921. See Foster, supra note 33, at 151.

289. See Chemerinsky, supra note 45, at 710-11 (noting that the Parsonage Exemption was a part of the Revenue Act of 1921, but the Minister's Housing Allowance was not codified until 1954).

290. Freedom from Religion Found., Inc. v. Lew, 983 F. Supp. 2d 1051, 1067 (W.D. Wis. 2013), vacated, 773 F.3d 815 (7th Cir. 2014).

291. See Foster, supra note 33, at 155 ("Eventually ... the United States Tax Court held that persons in other religions holding a status equivalent to those already benefitting from the exclusion also were entitled to the exclusion.").

292. Town of Greece v. Galloway, 134 S. Ct. 1811, 1816 (2014).

293. Lew, 983 F. Supp. 2d at 1056.
} 
arguing that the Minister's Housing Allowance discriminated against them as atheists; rather, the FFRF was arguing that the discrimination was linked to their inability as employees of a non-profit to benefit from a tax exemption that was only granted on the basis of religion. ${ }^{294}$

Ultimately, the Minister's Housing Allowance fails the historical test. Although property tax exemptions for religious organizations can be rooted in an historical tradition, there is no historical tradition that clearly shows ministers can deduct from their income portions of their salary that is used for housing. Because there is no tradition of ministers being exempt from federal income taxes, the Minister's Housing Allowance fails the historical test.

\section{The Minister's Housing Allowance Fails the Neutrality Test}

Another test applied by the Supreme Court that is favored by some justices is the neutrality test. ${ }^{295}$ In Mitchell v. Helms, the issue before the Court was whether federal funds that were distributed to state and local government agencies and then distributed to public and private schools violated the Establishment Clause when some of the private schools receiving funds were religiously affiliated. ${ }^{296}$

Justice Thomas, joined by three other justices, wrote that "[W]e have consistently turned to the principle of neutrality, upholding aid that is offered to a broad range of groups or persons without regard to their religion." ${ }^{297}$ The court went on to state that government aid does not violate the Establishment Clause when aid "is allocated on the basis of neutral, secular criteria that neither favor nor disfavor religion, and is made available to both religious and secular beneficiaries on a nondiscriminatory basis. $" 298$

To apply the neutrality test as stated in Mitchell v. Helms to the Minister's Housing Allowance, the issue becomes whether the tax exemption granted to "ministers of the gospel" is: (1) granted on the basis of neutral, secular criteria; (2) neither favors nor disfavors religion; and (3) is made available to both religious and secular beneficiaries. ${ }^{299}$

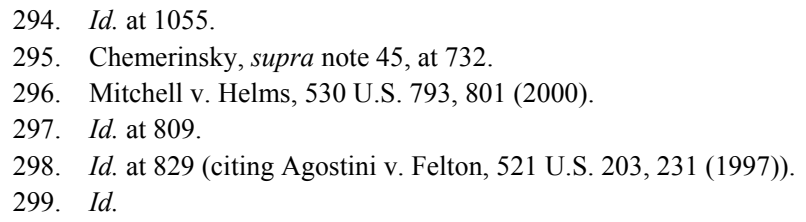


The Minister's Housing Allowance is not granted on the basis of neutral, secular criteria. First, the exemption can only be claimed by employees of a religious organization, which excludes secular employees right from the start. Determining whether a person is a "minister of the gospel" requires looking at the tenets and practices of the religion as well as the performance of other sacerdotal functions. ${ }^{300}$

The Minister's Housing Allowance also favors religion because it is an exclusive exemption for "ministers of the gospel." Unlike the Parsonage Exemption that has a corresponding exemption available to employees of non-religious organizations, the Minister's Housing Allowance has no corresponding secular tax exemption. ${ }^{301}$

For the above reasons, the Minister's Housing Allowance fails the neutrality test because: (1) it is not granted on the basis of neutral, secular criteria; (2) it favors religion; and (3) it is not available to both secular and religious beneficiaries. On its face the exemption is available only to "ministers of the gospel.",302

\section{The Future and Implications of The Minister's Housing Allowance}

Although the district court ultimately found the Minister's Housing Allowance to be in violation of the Establishment Clause in Lew, the court left open the possibility that the law could be re-written in such a way to pass constitutional muster. ${ }^{303}$ The primary fault in $\S 107(2)$ is that it applies exclusively to "ministers of the gospel." If the exclusion was expanded to include other nonreligious beneficiaries, the law could survive even though it also benefits religious groups. Such an expansion would have a few profound results.

First, the Parsonage Exemption is a perfect example of how an expansion of the Minister's Housing Allowance could benefit nonreligious persons while preserving the exemption for ministers. The Parsonage Exemption does not violate the Establishment Clause because there is a corresponding tax provision in the tax code granting exclusions for employees who are provided housing from non-religious employers. ${ }^{304}$ If Congress wished to change the tax code so the Minister's Housing Allowance does not violate the Establishment

\footnotetext{
300. See Knight v. Comm'r, 92 T.C. 199, 204 (1989).

301. See supra Section II.A.

302. Treas. Reg. § 107(2) (2014).

303. Freedom from Religion Found., Inc. v. Lew, 983 F. Supp. 2d 1051, 1073 (W.D. Wis. 2013), vacated, 773 F.3d 815 (7th Cir. 2014).

304. Treas. Reg. § 119 (2014).
} 
Clause, it could create a corresponding tax provision for non-religious employees that would eliminate any discrimination and any endorsement of religion.

Second, such a provision could profoundly benefit non-profit organizations. If employees of non-profits were able to exclude their housing from their gross income, non-profits would be able to be more competitive in their hiring decisions and potentially bring on higher caliber employees whose lower salary from the non-profit would be offset by the tax exclusion. A tax exclusion extended to non-profits would also allow non-profits to lower their salaries offered to employees because the money saved by the exclusion would offset the reduction in salary. This would free up more funds for non-profits to spend directly on programs that benefit the general welfare.

And finally, one of the problems with the Minister's Housing Allowance as it stands today is that it can be abused. It can be abused by ministers who are receiving high levels of income and exempting from their income the rentals and mortgages for extravagant housing. ${ }^{305}$ It can also be abused at a lower level of income. Churches can offer extremely low salaries to ministers and justify these lower salaries because the minister can exclude his mortgage or rent from his income.

Regardless of possible abuses, an expansion of the Minister's Housing Allowance to include other directors of non-profits could have a positive impact upon the ability of these non-profits to further their missions as well as maintain the Minister's Housing Allowance for ministers who are dependent upon the tax exclusion for their financial survival.

\section{CONCLUSION}

Although the Seventh Circuit ultimately reversed the district court on the issue of standing, it appears that the plaintiffs in Lew came as close as a plaintiff can come in establishing standing to challenge the Minister's Housing Allowance. Plaintiffs Barker and Gaylor were employed by a non-profit organization and portions of their salaries were designated as a housing allowance. ${ }^{306}$ Although Barker and Gaylor appear similarly

305. See Warren v. Comm'r, 282 F.3d 1119 (9th Cir. 2002).

306. Freedom from Religion Found., Inc. v. Lew, 983 F. Supp. 2d 1051, 1055 (W.D. Wis. 2013), vacated, 773 F.3d 815 (7th Cir. 2014). 
situated to ministers, the Seventh Circuit concluded that since they did not claim the exemption, they did not suffer an actual injury. ${ }^{307}$

Yet, the Minister's Housing Allowance appears to violate the Establishment Clause because: (1) it does not have a secular purpose; (2) it can be reasonably seen as a government endorsement of religion; (3) it fosters excessive entanglement between government and religion; (4) it is not rooted in an historical tradition; and (5) it violates government neutrality with religion. Ultimately, it must be concluded that, for the time being, the Minister's Housing Allowance is a political question. If plaintiffs cannot establish standing to challenge the Allowance, then the Allowance will remain unchanged unless Congress determines otherwise - a result that is extremely unlikely.

Although this Comment argues that the Minister's Housing Allowance is unconstitutional, it is not meant to be an assault on religion. As Judge Crabb stated in Lew, "Some might view a rule against preferential treatment as exhibiting hostility toward religion, but equality should never be mistaken for hostility." 308

307. Freedom from Religion Found., Inc. v. Lew, 773 F.3d 815, 821 (7th Cir. 2014).

308. Lew, 983 F. Supp. 2d at 1054 (emphasis added). 